\title{
SIMBOLISMOS E DESENCANTOS: ROCHA POMBO E A ESCRITA DE NO HOSPÍCIO
}

\section{SYMBOLISMS AND DISENCHANTMENTS: ROCHA POMBO AND THE PIECE OF WRITING AT THE ASYLUM}

\author{
Silvia Gomes Bento de Mello ${ }^{1}$
}

\begin{abstract}
RESUMO: O presente artigo tem por objetivo problematizar o romance No hospício (1996), escrito por José Francisco da Rocha Pombo, entre 1896 e 1900. Mais especificamente, se deseja capturar na trama, elementos que vinculam a obra a questões mais amplas tanto da vida de seu autor, quanto do momento histórico em que ele viveu. Dessa forma, vinculado à estética simbolista, o texto literário em questão revela um processo de crise da modernidade (em especial, vinculada aos valores da racionalidade), largamente denunciado nas páginas do romance. De outra parte, o entendimento da obra requer considerar que a escrita do romance só foi possível a partir das vivências e experiências do próprio escritor, que o levou a se decepcionar com o projeto da modernidade.
\end{abstract}

Palavras-chave: literatura; modernidade; loucura; hospício.

ABSTRACT: The present article aims to question the novel At the asylum (1996), written by José Francisco da Rocha Pombo between 1896 and 1900. More specifically, collect elements in the plot that link the literary composition to more broadened issues of the author's life as well as to historic moments in which he lived. Thus, connected to the symbolist aesthetics, the literary text studied reveals a process of modernity crisis, related especially with values of rationality widely reported in the novel. Nevertheless, the comprehension of the writing demands that the readers consider that the novel was based only on the author's own experiences, which led him to be disappointed with the modernity project.

Keywords: literature; modernity; madness, asylum.

\section{NO HOSPÍCIO E O DESENCANTO COM A MODERNIDADE}

No hospício (1996), romance publicado em 1905, por José Francisco da Rocha $\mathrm{Pombo}^{2}$, é comumente lembrado por ser o único exemplar brasileiro, em prosa, da

\footnotetext{
${ }^{1}$ Doutora pelo Programa de Pós-Graduação em História da Universidade Federal de Santa Catarina, UFSC e professora do Departamento de História da Universidade Estadual do Centro-Oeste, UNICENTRO, campus Santa Cruz/Guarapuava/PR. E-mail: silviagbmello@gmail.com

${ }^{2}$ José Francisco da Rocha Pombo (Morretes, 1857 - Rio de Janeiro, 1933) foi um escritor, jornalista e político que teve significativa presença no ambiente intelectual do Paraná, nas últimas décadas do século
} 
vertente Simbolista. De fato, a corrente francesa se notabilizou pelas suas manifestações em poesia. Adentrar pela escrita de Rocha Pombo, especialmente através do romance em questão, será o propósito do artigo que ora se inicia: capturar no enredo elementos que vinculam a obra a questões mais amplas tanto do mundo que a viu surgir quanto da vida de seu autor. Nesse sentido, consideramos a obra emblemática, não apenas pela relevância que lhe é atribuída na carreira intelectual do escritor ou na história do Simbolismo no Brasil, mas por percebermos nela uma densidade intelectual que bem expressa uma encruzilhada de questões que consideramos relevantes de serem discutidas a respeito da modernidade brasileira.

A temática do hospício é bastante pertinente a um processo modernizador que fora consagrado pelos valores da racionalidade: a loucura, avesso indesejado da razão, ganha uma instituição própria para problematizá-la e excluí-la. O hospício pode ser tomado, assim, como um lugar privilegiado para o entendimento da modernidade, afinal, como bem apontou Michel FOUCAULT (2002), longe de ser naturalmente um fato médico, a loucura é um fato de civilização. Na arqueologia empreendida por Foucault, entendemos as razões pelas quais, no mundo moderno, a loucura torna-se patologia e ao louco é destinado o emudecimento. De fato, a razão calou a loucura e não nos comunicamos mais com os loucos.

A obra de Rocha Pombo trata, justamente, disso. O intelectual paranaense toma a clausura de um hospício como um lócus de crítica à modernidade e à sociedade burguesa: lá é internado Fileto, personagem central da obra, pelo pai - "tenebroso tipo de burguês enriquecido" (POMBO, 1996, p. 72) - que se incomodava com o temperamento do filho: sempre distante, aéreo, introspectivo, descuidado das boas maneiras e do trato social. O motivo, embora inconsistente, foi suficiente para segregar o moço que, no hospício, constrói, a partir da sua subjetividade, seu mundo e suas referências.

No hospício, Fileto faz amizade com outro interno, o narrador (personagem cujo nome desconhecemos). Este se interna voluntariamente - estabelecendo-se no cubículo ao lado do de Fileto -, com o intuito de conviver com ele, de tentar entender uma figura tão ímpar, tão cheia de ideias. Alguém que, nas palavras de sóror Teresa, enfermeira dos internos, "era original, ou antes tão singularmente dotado de excelências que se destacou do comum para fazer jus a um hospício" (POMBO, 1996, p. 58). Nenhum dos 
dois - nem Fileto, nem seu amigo do cômodo vizinho - eram propriamente loucos, mas viviam em um hospício, eram tratados como loucos e, por vezes, se faziam de loucos. A partir de então, os dois encetam uma profícua amizade, amalgamada por longas conversas, debates de fundo filosóficos e humanísticos que constituem no que há de mais substancial no livro. A empatia e a cumplicidade que ligam os dois amigos são o esteio que propicia uma narrativa intimista e centrada na dimensão mais densa das vivências humanas: o sofrimento, a solidariedade, o altruísmo, os medos, o amor marcando-a como uma obra caracteristicamente simbolista.

A filiação ao Simbolismo marca ainda um forte posicionamento crítico em relação à modernidade. De fato, a estética francesa - que teve como principais representantes no cenário de seu país de origem poetas como Charles Baudelaire, Stéphane Mallarmé, Arthur Rimbaud, Paul Verlaine - era representativa do homem angustiado com a exclusão e a miséria típicas das sociedades industriais do século XIX. O Simbolismo vincula-se profundamente com a percepção de um mundo decadente e opressor. Baudelaire, de uma maneira especial, exprime com grande habilidade as misérias humanas, através de uma arte que transformava o feio, o sujo e o mau do mundo em literatura de qualidade ${ }^{3}$. No que tange a Rocha Pombo, sua expressão simbolista, na obra publicada em 1905, se realiza, sobremaneira, pondo em visibilidade as contradições e violências encarnadas na instituição do hospício. Assim, compadecido da situação do amigo, o narrador é porta-voz das críticas aos excessos e egoísmos dos quais os homens são capazes. Assim, contra a burguesia, encarnada na obra pela família de Fileto, dispara: "E que luxo aquele da família em visitá-lo, em dar perante o público, mostras de falsa caridade e solicitude pelo infeliz, quando todos sabiam que ele estava sacrificado ao orgulho de uma ridícula nobreza" (POMBO, 1996, p. 73).

A crueldade de largar um parente na solidão de um hospício, o egoísmo e a falta de empatia, que tanto estranhamento causavam ao narrador, expressam também, conforme será problematizado mais adiante, a própria insatisfação do autor do livro, Rocha Pombo, com as concepções e práticas vingadas na modernidade - caracterizando, a partir da obra em questão, a maneira como o Simbolismo encarnou as contradições de seu tempo e possibilitando-nos inferir, desde já, as razões pelas quais o paranaense se vinculou à estética Simbolista. As instituições de exclusão, tão características da

\footnotetext{
${ }^{3}$ Para aprofundamento desta questão, ver: BODOI, 2005, p. 136-144.
} 
modernidade, encarnam, através do hospício, um modelo reprovável, desumano, violento. Nas palavras do narrador:

Que ciência é esta a que assim condena uma pobre criatura humana sem ouvi-la e abandona assim um espírito à solidão horrível de um hospício... Como é que não há no mundo quem se compunja daquele destino, ao menos para saber o que há de irremediável naquela tristeza!... Que ciência é esta que não cura os loucos!... Que sociedade então fizemos que não salva os perdidos!... (POMBO, 1996, p. 57).

Fileto é a personagem socialmente injustiçada, que encarna os questionamentos a respeito dos sentidos e dos limites entre a razão e a loucura, tão pertinentes naqueles contraditórios tempos modernos. E o narrador é a voz de denúncia, que nomeia as injustiças e o no sense do mundo em que viviam. É a partir do narrador que temos acesso a Fileto: aos seus olhos, o amigo teria as mais ternas e nobres qualidades. Era uma criatura elevada, portadora de valores que transcendiam as pequenezas mundanas e as contingências que o havia trazido ao hospício: "Não sou capaz refletir, nesta pobreza de linguagem humana, as cintilações daquela intensa luz" (POMBO, 1996, p. 68), confessa. O caráter intimista da obra - preocupada em esboçar as subjetividades das personagens - e Fileto voltado para dentro de si, ocupado com as questões que tangem à existência humana são alguns dos elementos que identificam a obra com o Simbolismo.

De fato, o livro centra-se no pensamento e nos escritos de Fileto e do narrador, que discorrem sobre temas como ciência, arte e filosofia, fazendo do hospício um lugar onde se poderia re-encantar o mundo e a vida; um lugar onde se poderia sonhar com um novo tempo, planejar uma nova sociedade. Essa era a ocupação daqueles personagens, que aproveitavam a tranquilidade do hospício, onde os dias transcorriam todos iguais, para elaborarem os pressupostos de uma sociedade futura: "uma nova sociedade é, pois, como se vê, o problema que se impõe ao pensamento e ao coração do século que inauguramos" (POMBO, 1996, p. 176), sintetiza o narrador.

A questão se mostrava, para ele, de sobremaneira ligada à organização das cidades. As urbes modernas, altamente populosas, seriam o reino dos vícios, das desagregações e das violências, estando, assim, na contramão de uma sociedade guiada pela solidariedade e pela fraternidade entre as pessoas. A crítica também se estendia ao Estado que, centralizando o poder, organizava políticas que definiam a vida da população, cometendo, muitas vezes, abusos nesse exercício: “o estado [...] é o domínio da injustiça e a iniquidade organizada" (POMBO, 1996, p. 231), escrevia Fileto. 
Uma cidade futura esboçava-se, então, nas conversas dos dois internos: falavam em pequenos núcleos urbanos, com, no máximo, uma centena de famílias, onde todos teriam trabalho, mas também boas horas de lazer, para cuidar de si. Um lugar que dispensaria um governo centralizado, sendo gerido comunitariamente e onde todos teriam acesso à educação, um bem que acompanharia a vida daqueles citadinos até a morte (POMBO, 1996, p. 170-182). Proclamavam, enfim, valores coletivos, que nada teriam a ver com os egoísmos e individualismos que imperavam nas grandes cidades modernas que, no dizer do narrador de No hospício (1996), seria o verdadeiro "mundo de Dante" (POMBO, 1996, p. 268). Almejavam uma cidade renovada, com novos valores e novos sujeitos:

Em vez de ricos e poderosos, teremos os bons e os grandes espíritos: em vez de democracia e de aristocracia, teremos ou a desídia de coração ou a augusta formosura moral. Em vez de reis das minas de ouro, em vez de reis do carvão de pedra, em vez de reis do petróleo, em vez de reis das estradas de ferro, teremos os belos tipos que encarnaram o espírito da tribo - teremos O SÁBIO, O POETA, O ARTISTA (POMBO, 1996, p. 179).

Sábios, poetas e artistas ganhavam, então, o estatuto dos mais legítimos representantes da sociedade futura e da cidade futura, sonhadas e planejadas nos escritos e nas conversas de Fileto e seu amigo. Em outro ponto do livro, aquelas três atividades - de sábio, de poeta e de artista - são postas, juntamente com "a irmã de caridade, o médico, o mestre, o apóstolo e o profeta como as representantes das funções sagradas da vida" (POMBO, 1996, p. 190). A vida era, então, pensada a partir de novos pressupostos, que em muito se distanciariam dos vigentes nas sociedades modernas e nas grandes cidades, nas quais figuras como banqueiros e engenheiros se destacavam.

De fato, é patente em toda a obra, os questionamentos sobre a condição humana e a degradação a que pareciam condenados o homem e a vida moderna. Ao mesmo tempo, nos escritos de Fileto ou nos seus diálogos com o narrador, por vezes, formulamse estratégias para "salvar" a humanidade ou restituir-lhe uma pureza perdida. É interessante notar que tal reflexão tenha sido feita, justamente, em um hospício e por homens tomados como loucos: Rocha Pombo confere, portanto, a esses homens a faculdade de pensar um mundo mais equilibrado, lúcido, justo e fraterno.

Quem são e onde estão os loucos e os são, nesse contexto? Ao embaralhar essas localizações, Rocha Pombo explicita as contradições da modernidade e da 
racionalidade. A respeito disso, pode-se lembrar do escritor francês Antonin Artaud (1896-1948), internado em um hospício durante nove anos (1937-1946):

E o que é um autêntico louco? É um homem que preferiu enlouquecer, no sentido em que socialmente se entende a palavra, a trair uma certa ideia de honra humana. [...] Pois um louco é também um homem a quem a sociedade não quis ouvir e a quem quis impedir a expressão de insuportáveis verdades. (FRAYZE-PEREIRA, 1984, p. 11).

A passagem poderia ter sido dita por Fileto. Há, de fato, na personagem de Rocha Pombo um compromisso profundo consigo mesmo e com a sua verdade, mas é um compromisso que reverbera a crença de que nenhum ser humano deve trair a si mesmo. Fileto ancora-se em si: "para mim, ser emancipado é estar no caso de obedecer sempre, exclusivamente, a minha consciência. Não há deveres fora da minha moral" (POMBO, 1996, p. 233), sentencia. Sua preocupação girava em torno do homem, suas condições de liberdade e de consciência de si e do seu entorno, para gerar uma sociedade mais autônoma e feliz. A condição de liberdade que Fileto reivindica para si, ele reivindica para a humanidade: afinal, afirmava tal liberdade como condição do surgimento do novo - de um homem novo, de uma sociedade nova.

No entanto, ironicamente, Fileto vive enclausurado em um hospício: é de lá que ele pensa, opina e escreve sobre o mundo e a vida que se desenrolam para além dos muros da instituição. O hospício era um lugar de exceção: lugar e exílio e de liberdade de reflexão, onde a vida acontecia dissociada do mundo exterior.

Ao final do romance, o narrador insiste com Fileto na importância de que eles saíssem do hospício, chegando a sugerir uma fuga. "Quem conceberia que nos resignássemos a esperar aqui pela morte... quando a terra é tão vasta e tão bela!..." (POMBO, 1996, p. 235). E acrescenta: "Demais: bem se vê que estou são, como o senhor, e que só parecemos doentes enquanto estamos no hospício..." (POMBO, 1996, p. 235). De fato, para o narrador, o hospício significava uma espécie de morte social. Era preciso enfrentar o mundo, com suas mazelas e belezas. Para ele, diferentemente do que era para Fileto, a liberdade não poderia ser algo que se restringisse a esfera do pensamento. Ser livre incluía a autonomia de ir e vir. Contudo, Fileto, não compactuando com a opinião do amigo, acaba por morrer no hospício. Ele encontrava conforto em sua vida contemplativa, ocupado com ideias, livros e escritos, não necessitando tanto da ação, como seu amigo do cubículo vizinho. 
Fileto era alguém que acreditava na força das palavras, no seu poder de concentrar toda a intensidade de vida do seu enunciador. Através dela, ia-se além do real, além do visível, além do tangível, além das formas. Por isso, sua dedicação extrema às palavras, a descobrir novos usos, ao uso intenso de metáforas. A questão da linguagem constituiu-se como preocupação central no pensamento de Fileto, que postulava as condições para que ela bem expressasse o que lhe ia na alma:

As almas [...] procuram na palavra, na forma, na cor, no som, formosuras ideias e intangíveis. Esquadrinhai a palmeira ou o céu; medi a piedade, a misericórdia ou o amor e já me provareis que vossos olhos submissos à figura, não tem a precisa intensidade visual para além da matéria (POMBO, 1996, p. 76-77).

O desejo de Fileto por uma linguagem capaz de transcender a matéria e elevar o homem atesta a identificação da obra com o Simbolismo e a grande afinidade que Rocha Pombo estabeleceu com a corrente: assim, não apenas escreve um romance a partir das questões pertinentes a essa tendência literária - tais como a subjetividade, a crítica à modernidade e à sociedade burguesa, a valorização da morte -, como exerce uma reflexão sobre a concepção simbolista de linguagem. Com efeito, a necessidade de expressar a subjetividade e as questões humanas mais íntimas esbarra na questão da linguagem.

Daí a afirmação de uma linguagem simbólica e metafórica, baseada na evocação e na sugestão e que permitisse vislumbrar as realidades ocultas, as realidades da alma. Assim, da mesma forma que Fileto reivindica uma nova sociedade, clama também por uma nova linguagem. Uma linguagem que o arrancasse do real, que o colocasse diante dos mistérios e da beleza da vida:

Parece mesmo deplorável extravagância da nossa natureza incompleta este capricho de reduzir a medida e a cadência as grandes emoções a que a alma se exalça em certos momentos. Como é que me hei de satisfazer com a harmonia material quando meu espírito anda vivendo de outras harmonias! Do mesmo modo que em toda a natureza - isto é, no mar, na estrela, no espaço, na árvore, no perfume, na luz, no movimento - procuro na linha, no som, na cor, na eloquência intangível do verbo, o signo excelente e invisível da vida (POMBO, 1996, p. 76).

Estabelecia, então, uma relação profunda entre a palavra e o mundo exterior, entre o verbo e a vida. "A grande questão [escrevia Fileto em um de seus cadernos] é 
achar a palavra, o signo da vida" (POMBO, 1996, p. 156). De fato, o poeta era investido, na concepção simbolista, da condição de decifrador dos mistérios do universo, da beleza, da verdade. Fileto era um poeta. Contudo, nem mesmo os poetas seriam capazes de decifrar plenamente a vida: haverá sempre algo para além da compreensão humana.

Assim, para Fileto, a mente humana seria incapaz de alcançar os fins absolutos da vida. Tal concepção vai de encontro ao espírito cientificista da modernidade, que acreditava tudo poder dizer, conhecer, desvendar. Par a par com a percepção da contingência humana, expressada por Fileto em seus escritos e conversas com o narrador, estava a percepção de que as palavras não comportavam dizer tudo, havendo experiências que ficariam na esfera do indizível.

Da mesma forma, os simbolistas acreditavam que, por força de sua arte, os poetas seriam capazes de atribuir valor ao que antes não tinha ${ }^{4}$. Os símbolos, de acordo com Baudelaire, eram um meio de possibilitar aos poetas se insinuarem por zonas intangíveis e obscuras, realizando correspondências entre essas realidades e o mundo corpóreo $^{5}$. A natureza é um templo, um bosque de segredos - sugere um célebre soneto baudelairiano $^{6}$ - na qual "cores e sons, imagens e coisas referem-se uns aos outros, revelando afinidades e consonâncias misteriosas" (ECO, 2004, p. 246).

Fileto também se dedica a refletir sobre os segredos guardados na natureza e a relação destes com a linguagem e a capacidade de se fazer mediações entre o símbolo e a palavra. No seu entender,

“assim como há almas que passam inabaladas ante o céu, o firmamento e a montanha, e não se agitam interiormente à vista de um inseto ou uma flor - não é a todos que fala o verbo, pois que o verbo, no que tem de augusto, só se faz entendido de almas verdadeiramente grandes" (POMBO, 1996, p. 76).

Os poetas e demais artistas eram sujeitos especialmente afeitos à percepção e à decifração dos símbolos - ainda que Fileto não restrinja a esse grupo a sensibilidade de realizar tal correspondência. Os artistas, conforme anteriormente inferido, teriam papel angular na sociedade futura sonhada por Fileto e seu amigo, pois que seriam eles

\footnotetext{
${ }^{4}$ Para aprofundamento desta questão, ver: ECO, 2004, p. 146-149.

5 No poema Correspondências, de Charles Baudelaire, publicado em Flores do Mal, encontramos a síntese dessa compreensão dos símbolos mediando as realidades tangíveis e intangíveis.

6 Trata-se de Correspondências. Ver: BAUDELAIRE, Charles. As flores do Mal
} 
importantes agentes de novos valores, referências e atitudes, que realizariam a ruptura com os desequilíbrios e injustiças reinantes nos governos e nas cidades modernas.

Assim, conjecturar a respeito de um futuro que libertasse os homens de opressões e sofrimentos trazia consigo a necessidade de se elaborar a respeito de outros temas, tidos como fundamentais para aqueles novos tempos, tais como a arte e a linguagem. Nos escritos de Fileto, essas elaborações se concretizavam:

Não tolero que me obriguem a dizer tudo... Quero que me entendam por uma palavra, por um movimento, por um sinal. É por isso que acredito que uma nova arte ainda está por vir, uma arte para os espíritos: uma arte que nos revele as grandes figuras apenas pelas diagonais... (POMBO, 1996, p. 156)

A linguagem e a arte desejadas por Fileto tomavam, conforme a passagem que antecede, os atributos do Simbolismo. Valendo-se de símbolos e sinais, o interno revela o seu interesse por uma linguagem sutil e não explícita, que conduzisse a realidades e revelações inesperadas. Os símbolos favoreciam, por exemplo, conexões com o atemporal e o imemorial, já que determinadas imagens e seus significados atravessariam as gerações ${ }^{7}$. Em uma época em que tudo era profanado, os símbolos estariam resguardados, pois se referiam a uma realidade ausente ${ }^{8}$.

Nas propostas de se pensar o caráter simbólico da linguagem, suas relações com o tempo e com a arte - ou a linguagem no tempo e na arte - entrevê-se o desejo de ir além do real, comprometendo-se com o onírico e a fantasia. O processo criativo, tanto no uso da linguagem verbal quanto da pictórica, realizava-se na medida em que o artista dava voz àquele universo de mistérios e sonhos. "A arte só se realiza quando há uma exata correspondência entre a vida interior e os meios de objetivação" (POMBO, 1996, p. 163), acreditava Fileto. Na busca por uma espiritualidade e na constituição de uma esfera de sonhos, a arte simbolista encontrava um meio de combater os domínios da racionalidade.

Clamava-se pelo imaterial e pelo incorpóreo, pelo sagrado e pelo desconhecido como formas de afastar-se do comum e do ordinário e sobreviver às violências identificadas no mundo. Tratava-se, então, de "buscar um fundo que sustentaria os fenômenos, [seja ele chamado de] Absoluto, Deus ou Nada” (Bosi, 2002, p. 263). Uma

\footnotetext{
${ }^{7}$ Para aprofundamento desta questão, ver: GAGNEBIN, 1999, p. 31-53.

${ }^{8}$ Para aprofundamento desta questão, ver: OLIVEIRA, 2004, p. 70-71.
} 
referência que sustentasse o homem ante um mundo em intensas transformações, no qual tradições e antigos valores ruíam ou tinham seu lugar deslocado.

\section{Rocha Pombo e o desencanto com a modernidade}

Compreender o livro de Rocha Pombo requer, no entanto, ir além de sua interioridade, problematizando o próprio acontecimento de sua escrita. O texto do paranaense nos revelou uma insatisfação pelos caminhos que a modernidade e a racionalidade tomaram e já insinuamos que tal insatisfação não se restringia ao enredo, mas expressava sentimentos e posicionamentos de seu autor, Rocha Pombo. Nesse sentido, uma vez que já conhecemos, em traços gerais, a trama do livro, cabe, na segunda parte deste artigo, problematizar No hospício (1996) a partir da trajetória de Rocha Pombo. Com efeito, a relação do paranaense com as letras era antiga: aos dezessete anos (1875), quando ainda morava em Morretes, sua cidade natal, publicou na revista fluminense A Escola, seu primeiro artigo, sobre educação. Em 1879 (quando tinha 21 anos), já escrevia inflamados artigos em defesa da abolição da escravatura e da proclamação da República, no jornal O Povo, que fundara em Morretes. No ano seguinte, muda-se para Curitiba e, a partir de então, principia-se na publicação de livros e torna-se cada vez mais intensa sua participação em periódicos.

A honra do Barão e Dadá, ou a boa filha são exemplos de romances, de orientação romântica, publicados por Rocha Pombo nos seus primeiros tempos de Curitiba (1881 e 1882, respectivamente). Observa-se que o tempo em que esteve vinculado ao Romantismo coincide com um momento de sua vida em que se engajou na luta por modernizar o Paraná: de fato, além de lutar pela abolição e pela República, Rocha Pombo também se envolveu na política - tendo sido eleito deputado na Assembleia Legislativa do Paraná, em 1887. O entusiasmo pela modernização do Paraná é, portanto, patente em suas atividades desde a juventude. Quando deputado, por exemplo, defendera a construção de ferrovias e abertura de estradas pelos interiores, a diversificação da agricultura, o desenvolvimento da indústria, o fomento da urbanização, a agilização da colonização por imigração europeia, idealiza a criação de uma universidade no Paraná. Seu pensamento estava, assim, em consonância com o entendimento e o entusiasmo pela modernidade dominante nas décadas finais do século XIX. 
Rocha Pombo pertence a uma geração que fortaleceu a palavra (escrita e falada) acreditando que ela fosse uma espécie de arma para enfrentar os dilemas sociais e construir um futuro mais próspero. Uma geração que se investiu de uma missão, a ser realizada através do jornalismo, da literatura, da palavra, da retórica. No contexto paranaense, Pombo fora figura pioneira nesse embate. Dessa forma, conforme lembrará, anos mais tarde, seu amigo Nestor Vítor - importante crítico do movimento simbolista brasileiro: "Não havia, assim, como Rocha Pombo, deixar de assumir proporções únicas e ganhar desusado prestígio naquele nosso pobre horizonte" (SANTOS, 1969, p. 63). Referia-se, aí, à maneira como se insinuou nas letras e constituiu espaços para sua escrita e para disseminação dos seus ideais: "Até [então] nenhum paranaense subira intelectualmente tão alto perante a opinião de seu meio, nenhum fizera carreira tão vertiginosa na imprensa e nas letras”, sentencia Nestor Vítor (SANTOS, 1969, p. 63), no esforço de recompor a história intelectual de seu estado natal. Rocha Pombo, de fato, viu "aquele pobre horizonte", a que se referiu o amigo, tomar ares um tanto mais modernos: Curitiba tornava-se paulatinamente mais cosmopolita, na medida em que o século findava e o Paraná, da mesma maneira, ia experimentando dias de maior progresso.

O intelectual fora um grande otimista em relação ao futuro de sua província natal: nos artigos apaixonados que escrevia para jornais e revistas, ao se colocar na tribuna da Assembleia Legislativa ou elaborar projetos políticos apostava no potencial mais democrático e includente da modernidade. Acreditava, assim, que as benesses trazidas pelos tempos modernos beneficiariam a todos os paranaenses, aproximando-os e colocando-os no mesmo nível de prosperidade e contribuindo para a consolidação de dias de paz e bem-aventurança.

Contudo, o entusiasmo juvenil não resiste aos primeiros tempos republicanos. Por um lado, experimenta vários percalços no período em que esteve envolvido mais diretamente com a vida pública: nenhum dos projetos que constituíram a espinha dorsal das suas lutas políticas se concretizaram - enfrentou grandes desgastes na Assembleia Legislativa controlada, então, por fazendeiros vinculados ao partido Liberal. E suas relações acabaram por ficar difíceis também com o seu próprio partido, visto que suas ideias contrariavam, muitas vezes, os interesses Conservadores ${ }^{9}$.

\footnotetext{
${ }^{9}$ No Paraná, a identificação com os partidos Conservador ou Liberal obedeceu muito mais a uma ordem de interesses locais ou de manutenção da tradição familiar do que propriamente uma afinidade com as ideias do partido. A grosso modo, os donos de engenho de erva-mate, instalados na região litorânea
} 
Para além da frustração e dos embates desgastantes na Assembleia, a eclosão da Revolução Federalista (1893-1895) foi decisiva para deixar Rocha Pombo deslocado no seu estado natal. Episódio sangrento, com cercos e saques em cidades, grande número de mortes, a Revolução Federalista gerou o clima de instabilidade e morte característico das guerras civis. Posteriormente, a historiografia paranaense cristalizou a participação do estado como decisiva e heroica para a vitória legalista: o Paraná teria significado resistência fundamental para conter o avanço federalista garantindo, assim, a soberania nacional.

No entanto, para além dessa historiografia festiva, é preciso pensar no caráter desagregador e violento de um combate armado que atravessa o cotidiano de uma região. E é justamente esse caráter que marca a vivência que teve Rocha Pombo durante o conflito: as violências cometidas durante a Revolução Federalista, a exemplo das circunstâncias brutais que envolveram a morte do Barão do Serro Azul, importante produtor de erva-mate do litoral paranaense - fuzilado pelos legalistas no quilômetro 65 da estrada de ferro Paranaguá-Curitiba, acusado de cumplicidade com os federalistas ${ }^{10}$ contribuíram imensamente para a sua desilusão em relação à República. A respeito disso, desabafa:

O que se passa ante meus olhos já não se limita à esfera dos erros que as nações podem cometer impunemente e que lhes fornecem o grande e inestimável benefício de provações de que elas tiram a consciência dos seus destinos. O que se passa ante meus olhos excede todas as loucuras humanas, filia-se à ordem dos crimes monstruosos que vêm da negação da moral, que bradam para as alturas e que parecem ficar pesando eternamente sobre a cabeça dos povos (POMBO (1980) apud BEGA, 2001, p. 170).

O testemunho de Rocha Pombo é contundente em relação ao seu posicionamento frente aos horrores da guerra que seriam, para ele, injustificáveis. A guerra era o reverso

ligavam-se ao Partido Conservador, destacando-se aí, Ildefonso Pereira Correia (Barão do Serro Azul), maior ervateiro do Paraná, líder do partido Conservador e protetor de Rocha Pombo. O partido Liberal era composto, de sobremaneira, pelos donos de fazenda de gado, situadas em regiões mais interioranas. Menos vinculados à oligarquia rural, os membros do partido Conservador mostravam-se mais simpáticos à causa Republicana. Contudo, muitas das posições políticas de Rocha Pombo - defensor da República, da abolição da escravatura, da modernização da economia - não representava unanimidade entre os Conservadores. Na defesa de seus ideais, Rocha Pombo acaba por se afastar dos interesses do partido que representava, criando divergências dentro dele.

10 Ildefonso Pereira Correia (Paranaguá, 1849 - Morretes, 1894), o Barão do Serro Azul, figura proeminente da sociedade paranaense do final do século XIX, foi sumariamente executado (sem processo legal ou acusação formal), juntamente com outras cinco pessoas, na madrugada de 20 de maio de 1894, constituindo marcante acontecimento da Revolução Federalista em solo paranaense. 
da civilização a que ele tanto ansiava. A guerra era a barbárie. Nesse sentido, a Revolução Federalista foi uma experiência vigorosa também por colocar a República em causa: o intelectual viveu, a partir do embate armado no Paraná, os conflitos entre a República que idealizara e a realidade do regime em vigor. Assim, se a República trazia consigo a promessa de maior igualdade e democracia, o enfrentamento entre federalistas e legalistas acabou por acarretar um desencantamento: as violências, as perseguições e a falta de humanidade nada tinham a ver com os ideais republicanos que acalentava.

Ao fim do conflito, com a vitória florianista, Vicente Machado (1860-1907), que assumira o governo do Paraná quando os federalistas gaúchos invadiram o estado, ficou ainda mais fortalecido. Rocha Pombo nunca simpatizara com as ações e as ideias desse estadista e este foi mais um elemento que confluiu para que não mais se sentisse à vontade no Paraná. Assim, a partir desse conjunto de episódios, Pombo não mais encontra lugar ou acolhida no meio político curitibano. Ironicamente, seu envolvimento extremo com a política, seu empenho desmedido em modernizar o Paraná, o compeliriam a deixar o seu estado natal. Seu mandato de deputado já havia, então, terminado.

O Barão do Serro Azul, amigo com quem poderia contar, inclusive, como protetor político, falecera. Essas circunstâncias fizeram da sua permanência no Paraná algo cada vez mais difícil: ainda assim, lá persiste por mais três anos após o fim do conflito Federalista, para só então (1897) decidir-se pela mudança para o Rio de Janeiro - lugar mais indicado para um intelectual, um homem de letras no Brasil de então. Conforme sintetizou seu amigo Nestor Vítor, que bem conhecia a natureza do seu compromisso com o Paraná, "para atirar-se, pois ao mar, pensava eu, era mister que lhe faltasse de todo a terra aos pés, que moralmente o reduzissem à situação de um proscrito" (SANTOS, 1969, p. 60). De fato, foi esse amigo o primeiro a ir ao encontro de Rocha Pombo na terra carioca:

Recebi algumas linhas suas dizendo-me que vinha [...]. Fui encontralo à noite do mesmo dia em que chegou, instalado com oito pessoas num hotel, aparentemente tranquilo, até mesmo alegre, embora com cinquenta mil reis apenas no bolso ${ }^{11}$ (SANTOS, 1969. p. 60).

A mudança marcaria um divisor de águas na sua vida pessoal e profissional. A escrita de No hospício (1996) se relacionou a esse contexto: com efeito, embora tenha

\footnotetext{
${ }^{11}$ As oito pessoas a que Nestor Vítor se refere são a esposa de Rocha Pombo, Carmelita Madureira, e os filhos do casal.
} 
começado a escrever o romance em questão no ano anterior a sua partida para a capital federal, foi nos primeiros tempos em que lá viveu que amadureceu e finalizou o livro. Bem se percebe, a partir do que foi anteriormente exposto, que a obra foi elaborada quando o autor vivia um desencantamento em relação à modernidade desencantamento característico dos escritores simbolistas. Nesse sentido, o Simbolismo não pode ser meramente reduzido a um movimento de exportação, conforme defenderam Silvio Romero ou José Veríssimo ${ }^{12}$.

Ao menos No hospício (1996), obra frequentemente tomada como das mais significativas do Simbolismo brasileiro, foi gestada a partir de uma vivência de frustrações em relação à modernidade, o que se aproxima do contexto de surgimento da estética no âmbito francês.

Com efeito, quando analisamos a obra de Rocha Pombo percebemos que o Simbolismo surgiu paulatinamente no seu universo intelectual, enquanto foi se distanciando dos projetos que o animaram na juventude. Sua escrita vai se tornando mais pessimista, enfim, na medida em que se decepciona com os caminhos que a modernidade vinha tomando, especialmente no Paraná.

O enredo do livro, conforme previamente problematizado, evidencia as dificuldades e as injustiças do mundo moderno: as críticas às cidades inchadas, à inoperância do Estado, ao egoísmo humano, ao excesso de racionalidade. Distante está, portanto, dos artigos e discursos otimistas de outros tempos de sua carreira. Aliás, nesse movimento de desilusão em relação à modernidade, refugia-se cada vez mais na literatura - afastando-se da esfera mais ativa da vida pública e mesmo do jornalismo mais combativo. A literatura abarcará as questões que antes eram resolvidas na esfera pública: é escrevendo No hospício (1996) que Rocha Pombo dará voz aos seus descontentamentos e críticas aos rumos que vinha tomando a República, a modernização dos centros urbanos, os excessos de cientificismo.

Pombo preferirá, a partir de então, a companhia de rapazes que despontavam nas letras, sujeitos fortemente movidos pelo encantamento pela literatura, pelo jornalismo e cativados pela figura do intelectual morretense: "rodeamo-lo como a um prezado mestre" (SANTOS, 1969, p. 67), pondera Nestor Vítor - um daqueles rapazes. Comumente, os simbolistas se organizavam em pequenos grupos, formando espécies de irmandades, dada a tendência que tinham de ligarem-se afetivamente, através de

\footnotetext{
${ }^{12}$ Para entendimento desta questão, ver: BOSI, 2002, p. 261-300 e BROCA, 1975, 126-135.
} 
relações de admiração, respeito e carinho que extrapolavam os limites das discussões e interesses meramente literários. Esse também foi um encaminhamento de Rocha Pombo. Embrenhar-se pelo Simbolismo também significou, para ele, a constituição de novas sociabilidades, de novas maneiras de se relacionar - distante da burocracia política ou mesmo do trabalho formal no jornalismo. Preferia, agora, relações nutridas pela empatia, pela confiança, pela amizade: o aspecto subjetivo e humano, tão constitutivo da estética Simbolista, também se revela na maneira de viver e de se relacionar desses artistas.

Assim, Rocha Pombo aproxima-se também do grupo Cenáculo ${ }^{13}$, pequena irmandade formada por quatro rapazes de Curitiba, considerado um dos mais importantes focos de gestação do Simbolismo brasileiro. Para a revista do grupo - uma publicação denominada $O$ Cenáculo - Pombo escreve alguns textos, dentre eles, um conto significativo no seu encaminhamento para a estética Simbolista: trata-se de Em torno da Terra (1896) - uma literatura na qual faz críticas veladas à modernidade, valendo-se da ironia, da galhofa, da irreverência, conforme demonstrei em trabalho anterior (Mello, 2016).

No conto em questão, o intelectual vale-se da estrada de ferro, símbolo inconteste da modernidade ocidental, como o grande mote para sua história. A ferrovia havia sido também o cenário de morte de seu amigo Ildefonso Pereira Correia, o Barão Serro Azul. Pontua-se aqui que, a escrita de No hospício (1996) não é algo desconectado da produção intelectual do escritor. Há um histórico de amadurecimento do intelectual em relação ao Simbolismo, marcados por pequenos escritos, de cunho mais intimistas e subjetivos, além da publicação de Em torno da Terra. É significativa também, nesse encaminhamento, a escolha por se manifestar através da literatura, afastando-se de linguagens mais técnicas - que marcara sua carreira na política.

Com efeito, No hospício (1996) está enraizado tanto na bibliografia como na biografia de Rocha Pombo. Nesse sentido, não é à toa que é considerada a obra máxima da carreira do paranaense: não é apenas o resultado de um amadurecimento intelectual e literário, mas está profundamente vinculada às suas experiências mais dramáticas. Consideramos, assim, que o livro revela profundamente seu autor. Rocha Pombo se vale de Fileto para manifestar suas insatisfações e angústias.

\footnotetext{
${ }^{13}$ Grupo formado em 1893 pelos rapazes Dario Vellozo, Silveira Netto, Julio Pernetta e Antonio Braga, que se reuniam periodicamente a fim de compartilhar experiências de leitura, escrita e oratória. Os quatro amigos foram responsáveis pela publicação de diversos artigos em periódicos curitibanos, além de terem fundado uma revista própria, $O$ Cenáculo, que circulou em Curitiba entre 1895 e 1897.
} 
Aliás, Fileto era como o seu autor: um visionário sonhador que também se vale da leitura e da escrita como um meio de combate. Fileto vivia metido nos livros: "Lia e escrevia, sem cessar, dia e noite" (POMBO, 1996, p. 70), conta sóror Teresa. Essas eram as ocupações da personagem, tanto no hospício quanto antes de lá ir viver embora com a chegada do vizinho do cubículo do lado, Fileto tenha passado a despender longas horas de conversa com ele, posto que percebeu se tratar de alguém tão inclinado à leitura, à escrita e às ideias filosóficas quanto ele.

Assim como Rocha Pombo, Fileto era incompreendido no seu meio e não teve mais lugar onde sempre vivera: Fileto é tirado da casa paterna; Rocha Pombo se vê coagido a deixar o Paraná. A personagem constrói seu novo mundo em um hospício. $\mathrm{O}$ autor reconstrói a vida no Rio de Janeiro. Ambos, no entanto, encontram na escrita o meio de sobreviver à solidão, à melancolia e à falta de perspectiva. Fileto estava envolvido na escrita de uma tese sobre psicologia e dizia ao narrador "que só escrevia o que tinha na alma para consolar-se da vida" (POMBO: 1996, p. 68). A escrita, portanto, por si só, aplacava as suas angústias. Rocha Pombo dedica-se a escrever No hospício (1996), obra que consumiu quatro anos de trabalho (1896-1900): período que se seguiu a Revolução Federalista, quando o escritor saiu do Paraná e vivenciou o tempo de adaptação no Rio. A escrita do mais famoso dos seus romances foi um mecanismo de enfrentar os desarranjos da vida e reorganizar-se intelectualmente: assim como para Fileto, para Rocha Pombo, a escrita torna-se a sobrevivência possível - mas, necessária! - para quem se viu à margem do mundo e da vida que tinha anteriormente.

Rocha Pombo parece poupar, no entanto, sua personagem de sentimentos como sofrimento e a decepção, que haviam tomado a ele próprio. Fileto não esperava muito da humanidade, nem tão pouco da vida:

não havia, em Fileto, a alta caridade dos gênios: ele é indiferente... é de uma indiferença absoluta pela ordem social e pela sorte dos homens. Nem havia, na sua alma, o egoísmo temporal e humano [...]: o homem sabia ter, pela sua própria existência, um desprezo bárbaro (POMBO, 1996, p. 128).

Talvez, Rocha Pombo estivesse aprendendo, justamente, semelhante desprendimento que atribuiu a sua personagem. Todavia, tal qual caracteriza Fileto, Rocha Pombo também recolheu-se em si mesmo das decepções sofridas na vida pública, assumindo uma postura distanciada, de reclusão em relação ao seu entorno: 
Prefiro impor à minha razão um silêncio sagrado e criar para meu coração uma atmosfera pacífica e ideal, uma grande ilusão santa, onde ele pode viver de benção e de preces, de tolerância, de perdão (POMBO, 1980, p. 111).

A passagem, na qual Rocha Pombo refere-se à postura que assumiu após a Revolução Federalista, bem poderia ser dita por Fileto. Fileto toma ainda o caráter quixotesco de seu autor: tanto um quanto outro foram considerados loucos, visionários, inadaptáveis à realidade, devido à compulsão que tinham por ler e escrever. Ambos ansiaram por uma sociedade mais justa, fraterna e igualitária, na qual a educação, o solo, o trabalho e o lazer fossem acessíveis a todos. E, nesse movimento, colocam em causa os limites do mundo em que viveram. Mas, sobretudo, mais do que enraizar Fileto num contexto de crise da modernidade (e anunciar, através da sua literatura, tal crise!), o escritor constitui uma personagem que é espelho de si: náufraga, refugiada, deslocada, vivendo nos confins, sobrevivendo nas linhas de fuga.

Rocha Pombo é, de fato, no contexto paranaense, paradigmático de tal experiência: talvez, nenhum intelectual tenha vivido, como ele, o desencantamento pela modernidade marcando tão profundamente sua obra e sua trajetória de vida. Tornando, assim, No hospício (1996), muito mais do que uma obra canônica da literatura nacional: o livro é uma expressão profunda da própria vida e experiências de Rocha Pombo.

\section{REFERÊNCIAS}

BAUDELAIRE, Charles. As flores do Mal. Tradução de Ivan Junqueira. São Paulo: Difusão Europeia do Livro, 1964. BEGA, Maria Tarcisa Silva. Sonho e Invenção do Paraná: geração simbolista e a construção da identidade regional. Tese [Doutorado em Sociologia]. São Paulo: USP, 2001.

BODEI, Remo. As formas da Beleza.Tradução de Antonio Angonese. Bauru: Edusc, 2005.

BOSI, Alfredo. História Concisa da Literatura. 40ª ed. São Paulo: Cultrix, 2002. BROCA, José Brito. A vida literária no Brasil - 1900. $3^{\mathrm{a}}$ ed. Rio de Janeiro: José Olympio, 1975.

ECO, Humberto [org.]. História da Beleza. Tradução de Eliana Aguiar. Rio de Janeiro: Record, 2004. FRAYZE-PEREIRA, João. O que é loucura. São Paulo: Brasiliense, 1884. FOUCAULT, Michel. História da Loucura. Tradução de José Teixeira Coelho Netto. $6^{\mathrm{a}}$ ed. São Paulo: Perspectiva, 2002.

GAGNEBIN. Jeanne Marie. Alegoria, Morte, Modernidade. In: História e Narração em Walter Benjamin. 2a ed. São Paulo: Perspectiva, 1999, p. 31-53. 
MELLO, Silvia Gomes Bento de. Narrativas da modernidade em Rocha Pombo: reflexões sobre uma literatura simbolista. In: Organon - Revista do Instituto de Letras da UFRGS. v. 31, n. 61(2016): 375-391. Disponível em:

<file:///C:/Users/Usuario/Downloads/64597-288886-1-PB\%20(4).pdf> Acesso em: 29 jul. 2018.

OLIVEIRA, Valéria Ochoa. Um olhar sobre as musas de Eliseu Visconti: a pintura do Foyer do Teatro Municipal do Rio de Janeiro. Dissertação [mestrado em História]. Uberlândia: UFU, 2004.

POMBO, José Francisco da Rocha. Para a história: notas sobre a Revolução Federalista. Curitiba: Fundação Cultural de Curitiba, 1980.

POMBO, José Francisco da Rocha. No hospício. Curitiba: Prefeitura Municipal de Curitiba, 1996. [coleção Farol do Saber]

SANTOS, Nestor Vítor dos. Rocha Pombo no Paraná. In: Obras Completas de Nestor Vítor, v. III. Rio de Janeiro. Fundação Casa de Rui Barbosa/Ministério da Educação e da Cultura, 1969. 